\title{
Od zbrodni przez media do wyroku
}

\author{
EWA GRUZA \\ ORCID: 0000-0001-7808-883X \\ Katedra Kryminalistyki \\ Wydział Prawa i Administracji Uniwersytetu Warszawskiego
}

Każdego dnia jesteśmy atakowani nadmiarem informacji. Jedni z nas je selekcjonują, świadomie czytając tylko to, co jest dla nich interesujące i ważne, inni zaczynają lekturę od wyróżniających się, rzucających w oczy nagłówków, jeszcze inni skupiają się na doniesieniach sensacyjnych. Bez względu na to, jak selekcjonujemy informacje, co do jednego nie ma wątpliwości — jesteśmy każdego dnia zalewani falą wiadomości o zbrodniach i tragicznych wypadkach. Gdybyśmy wyłącznie na podstawie doniesień medialnych mieli opowiedzieć, w jakim świecie żyjemy, to byłby to świat przerażający okrucieństwem, bezmyślnością, niewyobrażalną skalą zbrodni, nadużyć i oszustw. Czy pod wpływem informacji o zbrodniach i okrucieństwie zmieniamy się, czy jesteśmy podatni na taką formę manipulowania nami, czy medialna pseudorzeczywistość wpływa na nasze samopoczucie, postrzeganie otaczającego nas świata, a także na nasze decyzje? Czy potrafimy oddzielać rzetelną informację od sensacyjnej, czujemy się bezpiecznie i w jakim stopniu sytuacje takie wpływają na naszą psychikę?

$\mathrm{Na}$ wiele z tych pytań pewnie nigdy nie znajdziemy odpowiedzi, ale warto się zastanowić nad jedną szczególną sytuacją — jak relacja o zbrodniach ukazująca się w mediach wpływa na życie obserwatorów i osób bezpośrednio związanych z takim zdarzeniem. 
Każdy z nas chce żyć w pewnym dobrostanie. Chcemy czuć się komfortowo w każdym aspekcie życia, wykorzystywać możliwości, radzić sobie w różnych sytuacjach życiowych, aktywnie uczestniczyć w życiu społecznym, produktywnie pracować. Fundamentem takiego funkcjonowania jest zdrowie psychiczne ${ }^{1}$. Światowa Organizacja Zdrowia w przyjętej w 1948 roku definicji zdrowia określa ten stan jako kompletny dobrostan fizyczny, psychiczny i społeczny, rozumiany jako nie tylko brak choroby czy niepełnosprawności². Oznacza to, że o pełnym zdrowiu mówimy, gdy sprawnie funkcjonujemy w trzech równoważnych obszarach - fizycznym, psychicznym i społecznym. Problem pojawia się, gdy zaburzone zostaje funkcjonowanie w jednym z nich. W niniejszych rozważaniach najważniejszy jest obszar psychiczno-społecznego funkcjonowania. Ten dobrostan obejmuje emocjonalne, psychologiczne oraz społeczne samopoczucie i zakłada przeżywanie pozytywnych uczuć. Nie oznacza to, że osoby o dobrym zdrowiu psychicznym nie podlegają negatywnym emocjom, nie przeżywają strachu, smutku, gniewu czy nieszczęścia. Nie wchodząc głębiej w te rozważania, warto przytoczyć zaproponowaną definicję zdrowia psychicznego uwzględniającą zarówno specyfikę funkcjonowania tego obszaru, jak i wiele czynników wpływających obecnie na rozumienie, czym jest zdrowie psychiczne.

zdrowie psychiczne jest dynamicznym stanem wewnętrznej równowagi, która umożliwia osobom wykorzystywanie ich umiejętności w harmonii z uniwersalnymi wartościami społecznymi. Podstawowe umiejętności poznawcze i społeczne; zdolność rozpoznawania, wyrażania i modulowania własnych emocji, a także współczucia dla innych; elastyczność i zdolność radzenia sobie z niekorzystnymi zdarzeniami w życiu i pełnienia funkcji w rolach społecznych; a także harmonijny związek między ciałem a umysłem — to istotne składniki zdrowia psychicznego, które przyczyniają się w różnym stopniu do stanu równowagi wewnętrznej ${ }^{3}$.

${ }^{1}$ L. Gromulska, Zdrowie psychiczne w świetle dokumentów Światowej Organizacji Zdrowia, „Przegląd Epidemiologiczny” 64, 2010, nr 1, s. 127.

2 Constitution of The World Health Organization, was adopted by the International Health Conference held in New York from 19 June to 22 July 1946, signed on 22 July 1946 by the representatives of 61 States and entered into force on 7 April 1948, https:// apps.who.int/gb/bd/PDF/bd48/basic-documents-48th-edition-en.pdf\#page=7 (dostęp: 23.01.2020).

${ }^{3}$ S. Galderisi et al., Toward a new definition of mental health, „World Psychiatry” 14, 2015, nr 2, s. 231-233, za: iidem, Propozycja nowej definicji zdrowia psychicznego, „Psychiatria Polska” 51, 2017, nr 3, s. 408. 
Zdaniem autorów tej definicji komponenty zdrowia psychicznego obejmują na przykład: zdolność do zwracania uwagi, zapamiętywania i porządkowania informacji, rozwiązywania problemów, podejmowania decyzji i korzystania z własnego repertuaru umiejętności słownych i niewerbalnych w komunikacji i interakcji z innymi; zdolność rozpoznawania, wyrażania i modulowania własnych emocji; empatię, to jest zdolność do doświadczania i rozumienia tego, co czują inni, co ma duże znaczenie w skutecznej komunikacji i w interakcjach społecznych, między innymi poprzez umożliwianie przewidywania działan, intencji i uczuć innych czy elastyczność oznaczającą zdolność do modyfikowania własnego zachowania lub własnych planów w obliczu nieprzewidywalnych zdarzeń lub nowych faktów ${ }^{4}$. Takie ujmowanie zdrowia psychicznego uwzględnia różnice kulturowe, społeczne, subiektywne odczucia czy także rywalizujące z sobą profesjonalne teorie psychiatryczne $e^{5}$.

Żyjąc w społeczeństwie, modyfikujemy własne zachowania wobec pojawiających się nowych faktów, opisów nieprzewidywalnych zdarzeń, a także biorąc pod uwagę sposób odczuwania bezpieczeństwa, zwłaszcza publicznego. Oczekujemy od państwa jako organizacji zapewnienia nam bezpiecznej egzystencji, w tym takiego zorganizowania instytucji chroniących obywateli, ich życie, zdrowie, majątek, byśmy czuli się chronieni przed zjawiskami groźnymi dla ładu prawnego. W interesujący sposób pojęcie bezpieczeństwa publicznego definiuje S. Pieprzny, przyjmując, że bezpieczeństwo publiczne to stan istniejący w państwie przy uwzględnieniu zmieniających się warunków społeczno-gospodarczych, w którym człowiekowi i ogółowi społeczeństwa nie grozi żadne niebezpieczeństwo, niezależnie od źródeł, z którego miałoby pochodzić. Granice bezpieczeństwa zakreślone są przepisami prawa i wszystko to, co zakłóca te granice, tworzy niebezpieczeństwo ${ }^{6}$. Jest to zatem ciągły proces społeczny doskonalący mechanizmy zapewniające poczucie bezpieczeństwa.

4 S. Galderisi et al., Propozycja nowej definicji..., s. 408-409.

5 Zob. np. G.E. Vaillant, Pozytywne zdrowie psychiczne: czy istnieje definicja międzykulturowa? „Postępy Psychiatrii i Neurologii” 21, 2012, nr 4, s. 229-238.

6 S. Pieprzny, Policja, organizacja i funkcjonowanie, Kraków 2003, s. 36. 
Warto zatem się zastanowić, czy i ewentualnie jak doniesienia medialne o popełnionych zbrodniach mogą zakłócać bezpieczeństwo publiczne i naruszać dobrostan psychiczno-społeczny.

Sięgnijmy do jednej ze starszych legend miejskich rozpowszechnianych w Polsce w latach sześćdziesiątych i siedemdziesiątych ubiegłego stulecia - czarnej wołgi. Potarzano wówczas, że

do kursującej po mieście czarnej limuzyny marki Wołga wciągano i porywano dzieci, żeby sprzedawać ich krew, m.in. bogatym Niemcom chorym na białaczkę. W różnych wariantach wołgą podróżowały zakonnice i księża, Żydzi, SB, a nawet wampiry. W niektórych wersjach należało się bać tylko takiej wołgi, która miała firanki albo biały pasek na drzwiach. Inni wspominali o białych oponach. Czasami mówiło się, że limuzyna tylko odwraca uwagę od prawdziwego zagrożenia — białego fiata $125 \mathrm{p}$. „Czarna wołga” nie umarła z PRL-em, w zmutowanej wersji krąży dziś po Wielkopolsce jako czarne BMW

Jedno nie ulegało wątpliwości - opowieści te wzbudzały strach i panikę, że dzieci zostaną porwane. Rodzice zwiększali opiekę nad potomkami, a dość powszechne poczucie zagrożenia towarzyszyło znacznej części społeczeństwa.

Innym przykładem oddziaływania na społeczeństwo, jego poczucie bezpieczeństwa i poprzez to na dobrostan psychiczno-społeczny jest medialna narracja o zbrodniach. Na dużą skalę z sytuacją taką mieliśmy do czynienia w drugiej połowie lat sześćdziesiątych ubiegłego stulecia na Śląsku. To wtedy rozwijał swój proceder przestępczy ,Wampir z Zagłębia”, czyli Zdzisław Marchwicki, dokonujący zabójstw w okresie od 1964 do 1970 roku. Prasa rozpisywała się o grasującym Wampirze, a wyobraźnię czytelników rozbudzały nagłówki typu Strach wyjść na ulicę, będące nie relacją z działań seryjnego zabójcy, a cytatem z przemówienia Edgara Hoovera, dyrektora $\mathrm{FBI}^{8}$. Panująca psychoza strachu zmieniała zachowania ludzi. Ówczesną milicję obywatelską zasypywano donosami na sąsiadów, kolegów, znajomych. Kobiety bały się chodzić samotnie, tworzono grupy samopomocy mające na celu odprowadzanie i przyprowadzanie ich z pracy. Relacje medialne, często oparte na porównywaniu „spokojnej i bezpiecznej” Polski z niebezpiecznym i okrutnym ,Zacho-

${ }^{7}$ K. Godlewski, Czarna wotga i inne legendy miejskie, ,Gazeta Wyborcza” 6.01.2004 (dostęp: 25.01.2020).

${ }^{8}$ P. Semczuk, Czarna wołga. Kryminalna historia PRL, Kraków 2013, s. 9. 
dem", nie tylko nie uspokajały, a wręcz przeciwnie — budziły większe obawy.

Bliższa obecnym czasom była sprawa zabójstwa Madzi z Sosnowca. W styczniu 2012 roku cała Polska żyła domniemanym porwaniem, a faktycznie zabójstwem sześciomiesięcznej Magdaleny Waśniewskiej przez jej matkę Katarzynę. Na ekranach telewizorów oglądaliśmy przerażoną młodą matkę, płaczącą, szlochającą, wzbudzającą współczucie i aktywizującą ludzi do szukania porwanej dziewczynki. Opis porwania i emocjonalne zachowanie matki spowodowały, że ludzie bali się o swoje dzieci. Opiekunowie pilnowali wózków z niemowlakami, organizowano akcje poszukiwawcze. Ponownie na społeczeństwo padł cień strachu. Katarzyna W. okazała się świetną manipulatorką i kłamcą. Medialny spektakl rozgrywał sią na oczach milionów ludzi, gdy mała Madzia już nie żyła. Społeczeństwo poczuło się oszukane, wzbierała fala nienawiści do sprawczyni, grożono jej zabójstwem. Zamiast zrozpaczoną ofiarą stała się obiektem skrajnej nienawiści. Czy relacja o porwaniu, a następnie zbrodni zabójstwa mogła wpływać na decyzje procesowe? Wskazywał na to obrońca oskarżonej, wyrażając nadzieję, że na wyrok sądu nie będą wpływały emocje społeczne, jakie wywołuje sprawa Katarzyny W.: „Krzyk ulicy jest krzykiem ludzi, którzy tak naprawdę nie mają dostatecznej wiedzy procesowej i prawnej, aby rozstrzygać tę sprawę. Tylko sąd potrafi ustalić prawdę w tym procesie i w oparciu o te ustalenia można wydać sprawiedliwy wyrok" - mówił mecenas Ludwiczek ${ }^{9}$. W pewnym zakresie doświadczaliśmy tego samego w lipcu 2019 roku, gdy przekazano informacje o zaginięciu pięcioletniego Dawida Żukowskiego. Dziesięciodniowe poszukiwania zaginionego dziecka, aktywizujące społeczeństwo i organy porządku publicznego, zakończyły się odnalezieniem zwłok chłopca ${ }^{10}$. Ponownie doświadczaliśmy z jednej strony

${ }^{9}$ Katarzyna W. uznana za winna, ,Newsweek” 3.09.2013, https://www.newsweek.pl/polska/wyrok-w-sprawie-magdy-z-sosnowca-katarzyna-w-uznana-winna/0mvns2n (dostęp: 25.01.2020).

${ }^{10}$ K. Siałkowski, N. Frątczak, Policja znalazła ciało 5-letniego Dawida. „,Było ukryte w zaroślach”. Śledztwo w sprawie zabójstwa, „Gazeta Wyborcza” 20.07.2019, https://warszawa.wyborcza.pl/warszawa/7,54420,25012484,policja-znalezlismy-cialo-poszukiwanego-5-letniego-dawida-zukowskiego.html (dostęp: 25.01.2020). 
psychozy strachu przed porwaniami dzieci, z drugiej zaś solidarności z rodziną i chęcią pomocy w poszukiwaniach.

Przykłady te wskazują, jak medialna narracja o zbrodni wpływa na nasze zachowania, postawy i poczucie bezpieczeństwa. Opisy budziły przerażenie, stan zagrożenia, panikę i strach przed staniem się ofiarą zabójstwa czy porwania dziecka. Powodowały naruszenie dobrostanu psychicznego i społecznego. Zachwianie tej równowagi, dekompozycja trzech elementów dobrostanu składających się na zdrowie psychiczne powodują, że nie funkcjonujemy sprawnie i mamy poczucie zagrożenia naszego bezpieczeństwa. Tym samym mamy problemy ze zdrowiem psychicznym.

Przedstawione rozważania pokazują zależność zbrodni i mediów z punktu widzenia obserwatora, jego przeżyć i ich wpływu na poczucie bezpieczeństwa i zdrowie psychiczne obywateli. Spójrzmy zatem, jak sytuacje te wpływają na sprawców, a zwłaszcza ich szczególną kategorię - niesłusznie skazanych. Rocznie w Polsce około 250-300 osób otrzymuje odszkodowania za niesłuszne skazania i aresztowania. W mediach pokazywane są tylko najbardziej spektakularne uniewinnienia, często powiązane z zasądzonymi wysokimi odszkodowaniami i zadośćuczynieniami. Nie ma jednak żadnej refleksji nad losami osób niesłusznie skazanych oraz ich rodzin. Jeżeli się o tym mówi, to najczęściej w trywialny sposób, sprowadzający się do podkreślania wysokości wypłaconych odszkodowań.

Pierwsza historia dotyczy niesłusznie skazanego Zbigniewa Góry oskarżonego o zabójstwo emerytowanej lekarki w Lublinie. Zabójca zabiera telefon komórkowy i biżuterię. Podejrzenie pada na kucharza Z. Górę, który wynajmuje od lekarki mieszkanie. Ktoś zeznaje, że chyba kupił ją od Góry, to wystarcza, aby w procesie poszlakowym skazać go na karę 25 lat pozbawienia wolności. Stara się jakoś przetrzymać w więzieniu. Żona nie wytrzymuje sytuacji i odchodzi. „30 listopada dostaję wyrok rozwodowy, a dwa tygodnie później wyrok 25 lat za zabójstwo. Taka kumulacja" - zauważa gorzko Zbigniew Góra. Walczy, odwołuje się od orzeczeń. Ostatecznie sąd uznaje, że nie ma dowodów na jego sprawstwo i zostaje on uniewinniony. Na wolność wychodzi po trzech latach spędzonych w zakładzie karnym. Jak podkreśla: 
Nikt mi nie mówi: przepraszam. Na szczęście z żoną znowu zaczęło się jakoś układać. Próbujemy żyć, udawać, że nic się nie stało. Ale ja nie umiem zmazać tego, co się stało. W zasadzie mam dożywocie. Już nie jestem Zbyszek Góra, kucharz. Tylko Zbyszek Góra, którego skazano za zabójstwo. Muszę z tym żyć. O moim zatrzymaniu było głośno. Nawet się o tym mówiło w programie „,997”. Ludzie mnie zaczepiają: „Ty, byłeś w »997«, o ja pierdzielę"11.

Mimo wyroku uniewinniającego nadal traktowany jest jak zabójca. Mieszkańcy lubelskiej kamienicy przy ul. Leśnej 15, spoglądając zza firanek, do dziś patrzą na Zbigniewa Górę jak na mordercę ich sąsiadki Haliny B., siedemdziesięcioletniej lekarki. Nieważne, że został uniewinniony. Dla nich jest winny, bo policja nadal szuka faktycznego zabójcy. Skazanie i wyrok zniszczyły dotychczasowe życie nie tylko Z. Góry, lecz także całej jego rodziny. Swoje przeżycia opisuje on w licznych wywiadach prasowych.

O tym, że żona chce się rozwieść, dowiedziałem się ponad rok od aresztowania. Złożyła pozew o rozwód, więc przestała we mnie wierzyć! Gdy trafiłem za kraty, młodszy syn - Przemek - miał 2,5 roku, starszy Łukasz 5,5. Im dłużej byłem w areszcie, tym Łukasz coraz bardziej odsuwał się ode mnie. W ostatnim liście napisał, żeby nie kontaktować się z nim, bo on już do mnie pisać nie chce. Musiał mi pomóc psycholog. Byłem w areszcie tymczasowym prawie trzy lata! ${ }^{12}$

W przejmujący sposób mówi o tej sytuacji Łukasz Góra - najstarszy syn:

Gdy tata poszedł do aresztu, miałem 6 lat. Na początku nie wiedziałem, co się stało. Mówiono mi, że wyjechał zarabiać do Włoch. Potem przeczytałem kilka artykułów w gazetach... Tam było napisane, gdzie jest tata... W szkole koledzy mi dokuczali. Szydzili, że ojciec był skazany za „niewinność”, a dostał karę 25 lat! Poszedł do więzienia w najważniejszym momencie mojego życia! Do dziś pamiętam, jak byłem bardzo rozgoryczony podczas Pierwszej Komunii. W kościele widziałem rodziny kolegów, ich rodziców, chrzestnych siedzących w ławkach. U mnie — tylko mama i babcia...

Zbigniew Góra: Dopiero po półtora roku od wyjścia z aresztu, od kiedy zacząłem z synem na nowo utrzymywać kontakt, powiedział mi: „Kocham Cię, tato!”.

11 M. Święchowicz, Niestusznie skazani: I tak mamy dożywocie, „Newsweek Polska” 15.09.2013, aktualizacja 16.11.2019, https://www.newsweek.pl/polska/niewinnie-skazani-na-newsweekpl/24589xs (dostęp: 25.01.2020).

12 Ibidem. 
Łukasz wyznaje: Dla mnie tata wciąż — w jakimś kawałku — jest osobą obcą. To mi na duszy siadło i do końca życia będzie siedzieć ${ }^{13}$.

Konsekwencje medialnego zainteresowania sprawą silnie odczuła też matka Zbigniewa Góry, codziennie patrząca znajomym i sąsiadom w oczy, z których odczytywała: „Twój syn jest mordercą”14.

Najbardziej znana jest sprawa Tomasza Komendy, niesłusznie skazanego na karę 25 lat pozbawienia wolności za zgwałcenie i zabójstwo piętnastoletniej Małgorzaty w noc sylwestrową 1996 roku, prawomocnie uniewinnionego przez Sąd Najwyższy wyrokiem z 16 maja 2018 roku. Dlaczego został skazany? Jak odpowiada Grzegorz Głuszak, reporter TVN24, autor reportażu o Tomaszu Komendzie: bo było ogromne parcie, żeby „tego zwyrodnialca” zatrzymać, osądzić i ukarać ${ }^{15}$. Ówczesna prasa rozpisywała się o sadystycznym zabójcy, drastycznej zbrodni, zwyrodnialcu, okrutnej zbrodni w Miłoszycach. Sprawca jawił się jako okrutny sadysta, pozbawiony uczuć, bezwzględny, zasługujący na śmierć. Narracja była jednoznaczna. Skazanie za gwałt i zabójstwo dziecka stygmatyzowało także w czasie odbywania kary. Znamienne są słowa jednego ze współwięźniów osadzonych w tym samym zakładzie karnym, w którym odbywał karę T. Komenda:

Dla niego na całe szczęście nie spotkaliśmy się [w jednej celi — przyp. autorki]. Nikt z ludzi, którzy nie siedzieli w więzieniu, nie zrozumie, co ten człowiek przeżył. [...] Gdybym mógł i nie poniósł za to konsekwencji, to bym go z przyjemnością zabił. Gdybym dostał pod celę pedofila, mordercę dzieci, tobym go z czystą przyjemnością zabił. Bez mrugnięcia oka, bez wyrzutów sumienia ${ }^{16}$.

Uniewinnieniu T. Komendy towarzyszyło zainteresowanie mediów, także tych, które osiemnaście lat wcześniej opisywały go jako sadystę i zwyrodnialca, wierząc w jego winę. Jak relacjonuje Grzegorz Głuszak, przed wyjściem ,z zakładu karnego czekały tłumy dziennikarzy, które na

13 A. Bogoryja-Zakrzewski, Niesłusznie skazany za zabójstwo walczył o 17,5 miliona złotych odszkodowania, https://www.e-reporter.pl/2017/01/28/nieslusznie-skazanyza-zabojstwo-walczyl-o-175-miliona-zlotych-odszkodowania/\# (dostęp: 25.01.2020).

${ }^{14}$ E. Rogowska, Trzy lata z piętnem mordercy, https://wiadomosci.onet.pl/kiosk/ trzy-lata-z-pietnem-mordercy/xsjnd (dostęp: 25.01.2020).

15 https://weekend.gazeta.pl/weekend/1,152121,24035082,zycie-tomasza-komendy-na-wolnosci-przez-tydzien-codziennie.html (dostęp: 25.01.2020).

16 G. Głuszak, 25 lat niewinności. Historia Tomasza Komendy, Kraków 2018, s. 258. 
widok T. Komendy wykrzykiwały: »Co pan czuje?, Dlaczego nie chce pan nam nic powiedzieć? «”17. Z bandyty i zbrodniarza w oka mgnieniu zmienił się w pozytywnego bohatera mediów.

Tomasz Komenda spędził w zakładzie karnym osiemnaście lat. $\mathrm{Z}$ trudem adaptuje się do życia na wolności. Sędzia Nowiński, który wydał orzeczenie o warunkowym przedterminowym zwolnieniu T. Komendy, zauważa, że osiemnaście lat pobytu w warunkach izolacji całkowicie zmienia człowieka. Kto ma do czynienia z osadzonymi, widzi po ich ruchach, zachowaniu, co przeszli, i że byli w warunkach izolacji więziennej. Podkreśla, że niezbędna będzie pomoc psychologa i innych specjalistów, by stopniowo wracał on do normalnego życia ${ }^{18}$. Jak relacjonuje w kwietniu 2019 roku pełnomocnik Tomasza Komendy: „stan psychiczny jest gorszy niż bezpośrednio po opuszczeniu więzienia. Ma takie dołki, że odłożyliśmy na razie czynności związane z przygotowaniem wniosku o zadośćuczynienie. Tyle lat za kratami robi swoje"19. Stopniowo Tomasz Komenda i jego rodzina uczą się żyć w nowych warunkach, z ,zabójcą”, który nigdy nim nie był, ale i bez piętna mordercy i gwałciciela. Paradoksalnie ci, którzy tak bardzo go piętnowali, dzisiaj piszą o nim jak o bohaterze.

We wszystkich tych sprawach media odpowiednio ,podgrzewały” atmosferę. Artykuły prasowe opatrywane były nagłówkami: Skazany za bestialski mord na 70-letniej emerytowanej lekarce, Sprawiedliwość triumfuje!, 25 lat za okrutne zabójstwo, Sprawca działał jak sadysta... $\mathrm{W}$ tekstach ukazujących się $\mathrm{w}$ różnych mediach uniewinnieni kiedyś przedstawiani byli jako bestie, zwyrodnialcy, mordercy. Tworzono psychozę strachu. W obu wskazanych przykładowo sprawach niesłusznie oskarżeni i skazani zostali uniewinnieni. Sądy wydały słuszne wyroki, uznając ich za osoby niewinne - wyroki słuszne nie tylko w poczuciu społecznym, ale przede wszystkim pod względem czysto prawnym ${ }^{20}$. Nie ulega jednak wątpliwości, że nawet taka narracja, kończąca się unie-

17 Ibidem, s. 239.

18 Ibidem, s. 250-251.

19 Tomasz Komenda byt w ztym stanie. Jest opinia biegłego psychiatry, https://www. wprost.pl/kraj/10204776/tomasz-komenda-byl-w-zlym-stanie-jest-opinia-bieglegopsychiatry.html (dostęp: 25.01.2020).

20 J. Wróblewski, Wartości a decyzja procesowa, Wrocław 1973, s. 212-213. 
winnieniem, pozostawia w ślad świadomości społecznej. Historie pokazują, że można zostać oskarżonym i skazanym za czyny, których się nie popełniło.

Nie ulega wątpliwości, że bezpieczeństwo jest wartością cenną i pożądaną. Poczucie bezpieczeństwa, i jego poziom determinowane, jest przez zagrożenia i zdolność państwa do skutecznego przeciwstawiania się im. Oznacza to, że obywatel ma prawo oczekiwać od państwa jako organizacji zapewnienia i ochrony bezpieczeństwa, gdyż dopiero zaspokojenie tej potrzeby umożliwia pełny rozwój człowieka ${ }^{21}$. Poczucie bezpieczeństwa wiąże się z zaufaniem, jakim obdarzamy otoczenie, w którym funkcjonujemy, także organy państwa; z umiejętnością pozytywnego skupiania się nad rzeczami, które nas otaczają, potrzebą stabilizacji i szacunku. Chcemy żyć w harmonii, a każda sytuacja, która ją zakłóca, powoduje utratę poczucia bezpieczeństwa. Niezaspokojenie tej potrzeby może wywołać doraźne stany lękowe, a nawet w skrajnych przypadkach prowadzić do trwałych zaburzeń w funkcjonowaniu układu nerwowego. Nie ulega zatem wątpliwości, że przyczyną poczucia zagrożenia może być także narracja medialna o zbrodniach. Krzykliwe nagłówki, treści zawierające opisy okrucieństwa, ilustrowane pobudzającymi wyobraźnię zdjęciami czy rysunkami, mocno oddziałują na większość z nas, niekiedy przyczyniając się do powstawania lęków. Stajemy się bardziej nerwowi, drażliwi i przestraszeni.

Czy w takich sytuacjach cierpi nasze zdrowie psychiczne? Dotyczy to zarówno obserwatorów życia, czytelników sensacyjnych artykułów w mediach, jak i tych, którzy doświadczyli traumy niesłusznego skazania. Zapewne nasz dobrostan psychiczno-społeczny zostaje naruszony, przynajmniej krótkotrwale. Ale nie można zbagatelizować tego, że obecnie szacuje się, iż około 25\% ludzi cierpi na różnego rodzaju zaburzenia psychiczne, a WHO przewiduje, że już w 2020 roku depresja będzie drugą najpoważniejszą przyczyną niepełnosprawności na świecie ${ }^{22}$. Na zachowanie dobrego zdrowia psychicznego wpływa wiele czynników, w tym język, jakim się posługujemy, a negatywne komunikaty obniżają nasze poczucie wartości, mogą wprawiać nas w stany lękowe. Czytanie

21 Wspótczesne zagrożenia bezpieczeństwa państwa, red. W. Lis, Lublin 2015, s. 7.

22 https://www.mp.pl/pacjent/psychiatria/aktualnosci/151284,jak-dbac-na-codzien-o-zdrowie-psychiczne (dostęp: 26.01.2020). 
o zbrodniach, przebywanie wśród ludzi agresywnych, których obecność nas drażni, zaburza nasze poczucie bezpieczeństwa. Doświadczamy zaburzeń lękowych, co utrudnia, a niekiedy uniemożliwia normalne funkcjonowanie. Zaczynamy być izolowani, egzystujemy na marginesie społecznym. Źródłem zaburzeń lękowych mogą być silne przeżycia, traumy. Doświadczamy fobii i lęków ${ }^{23}$.

Zadaniem mediów jest informowanie, sądów zaś — wymierzanie sprawiedliwości. Rolą państwa jest natomiast zapewnienie obywatelom realnego bezpieczeństwa, a także subiektywnego poczucia bezpieczeństwa. Nie od dziś wiemy, że medialnie najlepiej sprzedają się zło, przemoc, złe wieści. Być może takie jest zapotrzebowanie społeczne. Nie można zatem winić mediów, że wykorzystują tę zależność. Może to właśnie my jako społeczeństwo kształtujemy w pewien sposób rodzaj narracji o zbrodni w mediach i o wyrokach. Uniewinnienie przez sąd nie zawsze jest uznaniem za niewinnego przez społeczeństwo. Jakże często w obiegowych opiniach słychać, że coś musiało być na rzeczy, bo niewinnych nie aresztują i nie skazują. A jednak tak się dzieje... Manipulowanie faktami, drobne kłamstwa i insynuacje, przemilczanie części historii — te najbardziej znane techniki manipulacji stosowane są zarówno w życiu prywatnym, publicznym, jak i dziennikarskim. Warto zatem się zastanowić, jakie są tego konsekwencje.

Przede wszystkim rozważmy konsekwencje występujące w zakresie zdrowia psychicznego. Bez względu na to, czy relacje o zbrodniach dokonywane są z punktu widzenia obserwatora, zagłębiającego się w opisy miejsca czynu, ofiary czy sprawcy, czy też z perspektywy niesłusznie skazanego sprawcy, naruszony zostaje dobrostan psychiczny i społeczny. Doznajemy negatywnych uczuć, przeżywamy strach, smutek, gniew, wczuwamy się w nieszczęście innych. Zakłócona zostaje wewnętrzna równowaga, tym samym trudniej nam wykorzystywać własne umiejętności w harmonii z uniwersalnymi wartościami społecznymi. Górują negatywne emocje, zaburzona jest zdolność do rozpoznawania, wyrażania i modulowania własnych emocji, a także współczucia dla innych. Łatwiej ulegamy lękom i fobiom, podejmujemy mniej racjonalne decyzje.

23 Psychiatria, podręcznik dla studentów medycyny, red. A. Bilikiewicz, Warszawa 1998, s. 69. 
Relacje medialne i wiara w ich rzetelność powodują stygmatyzowanie nie tylko sprawców, lecz także ich rodzin, a niekiedy ofiar. Warto również wspomnieć o kosztach ekonomicznych. Nie są to tylko odszkodowania i zadośćuczynienia wypłacane ze środków Skarbu Państwa w wypadku niesłusznie skazanych, ale także koszty pomocy psychologicznej, lekarskiej, wzrost wydatków na leczenie, oraz organizację, infrastrukturę i działalność służb odpowiedzialnych za porządek i bezpieczeństwo. W zakresie bezpieczeństwa publicznego nie można pominąć konsekwencji wynikających ze stwarzania poczucia zagrożenia. Epatowanie zbrodnią, porwaniami, gwałtami stwarza w większości wypadków mylne przekonanie, że nasze otoczenie jest groźne, nieprzyjazne, a my w każdej chwili także możemy stać się ofiarami przestępstwa. Jednocześnie nie uświadamiamy sobie, że narracja odnośnie do relacji zbrodnia-mediawyrok bywa zmanipulowana przez półprawdy czy niedopowiedzenia, niemówienie całej prawdy. Odpowiednie przedstawianie przestępstw pozwala na manipulowanie poczuciem bezpieczeństwa, podważa zaufanie i szacunek na przykład do organów państwa, wpływa na podejmowane decyzje, zakłóca ład i harmonię. Łatwiej kontrolować społeczeństwo zdezorientowane, oczekujące na stabilizację i ład, w którym konieczne jest odbudowanie zdrowia psychicznego. Dlatego też należy mieć na względzie, że odpowiednio kontrolowana i sterowana narracja o zbrodniach może służyć pośredniej kontroli społeczeństwa.

Przedstawione rozważania są autorską próbą spojrzenia na trudne i skomplikowane relacje pomiędzy zbrodnią, jej opisem medialnym, a rzeczywistym zakończeniem postępowania, w szczególności przez pryzmat niesłusznych skazań. Sprawcy przestępstw w większości unikają rozgłosu, dokonują zbrodni w odosobnieniu, bez udziału fleszy i dziennikarzy. Dziennikarze starają się sprzedać tekst najbardziej sensacyjny, ociekający przemocą, okrucieństwem, bestialstwem, wiedząc, że tego oczekują odbiorcy. Zadaniem sądów jest sprawiedliwe, bezstronne i niezawisłe orzekanie. Gdzieś w tle natomiast naruszone zostają nasze istotne dobra — zdrowie psychiczne i poczucie bezpieczeństwa. 


\section{Bibliografia}

Bogoryja-Zakrzewski A., Niesłusznie skazany za zabójstwo walczył o 17,5 miliona złotych odszkodowania, https://www.e-reporter.pl/2017/01/28/nieslusznie-skazany-zazabojstwo-walczyl-o-175-miliona-zlotych-odszkodowania/\# (dostęp: 25.01.2020).

Galderisi S., Heinz A., Kastrup M., Beezhold J., Sartorius N., Propozycja nowej definicji zdrowia psychicznego, „Psychiatria Polska” 51, 2017, nr 3.

Galderisi S., Heinz A., Kastrup M., Beezhold J., Sartorius N., Toward a new definition of mental health, „World Psychiatry” 14, 2015, nr 2.

Głuszak G., 25 lat niewinności. Historia Tomasza Komendy, Kraków 2018.

Godlewski K., Czarna wotga i inne legendy miejskie, „Gazeta Wyborcza” 6.01.2004.

Gromulska L., Zdrowie psychiczne w świetle dokumentów Światowej Organizacji Zdrowia, „Przegląd Epidemiologiczny” 64, 2010, nr 1.

Pieprzny S., Policja, organizacja i funkcjonowanie, Kraków 2003.

Psychiatria, podręcznik dla studentów medycyny, red. A. Bilikiewicz, Warszawa 1998.

Rogowska E., Trzy lata z piętnem mordercy, https://wiadomosci.onet.pl/kiosk/trzy-lata-z-pietnem-mordercy/xsjnd (dostęp: 25.01.2020).

Semczuk P., Czarna wołga. Kryminalna historia PRL, Kraków 2013.

Siałkowski K., Frątczak N., Policja znalazła ciało 5-letniego Dawida. „Było ukryte w zaroślach”. Śledztwo w sprawie zabójstwa, „Gazeta Wyborcza” 20.07.2019, https:// warszawa.wyborcza.pl/warszawa/7,54420,25012484,policja-znalezlismy-cialo-poszukiwanego-5-letniego-dawida-zukowskiego.html (dostęp: 25.01.2020).

Święchowicz M., Niestusznie skazani: I tak mamy dożywocie, „Newsweek Polska” 15.09.2013, aktualizacja 16.11.2019, https:/www.newsweek.pl/polska/niewinnie-skazani-na-newsweekpl/24589xs (dostęp: 25.01.2020).

Vaillant G.E., Pozytywne zdrowie psychiczne: czy istnieje definicja międzykulturowa?, „Postępy Psychiatrii i Neurologii” 21, 2012, nr 4.

Wróblewski J., Wartości a decyzja procesowa, Wrocław 1973.

Wspótczesne zagrożenia bezpieczeństwa państwa, red. W. Lis, Lublin 2015.

\section{From crime through the media to sentence}

\section{Summary}

Every day we read about accidents, crimes, and felonies. Therefore, it is worthwhile thinking like media dazzled with the felony and cruelty, we are changing ourselves, as the narrative in the mass media can influence our mental health and sense of security. It is worthwhile looking at these problems not only from the perspective of the observer and the reader of media news reports, but also the unjustly sentenced, experiencing the effects of the media narrative.

Keywords: felony, media, mental health, safety. 